дополнительные исследования, поиск новых и усовершенствование предложенных методических подходов к анализу спутниковой информации.

Ключевые слова: дистанционные методы измерения осадков, очень сильные осадки, GPM IMERG, верифрикация, статистические параметры и индексы.

\title{
Satellite measurements of precipitation intensity and their verification
}

Sokur K., Palamarchuk L.

The main focus of this study was to establish the feasibility of working with the intensity data of individual events of very heavy precipitation (50 mm or more in 12 hours or less) observed over the territory of Ukraine using remote sensing data (satellite data GPM IMERG), as well as verification of satellite data with ground station data (self-recording rain gauge data). The study consisted of processing data and maps - IMERG products, building tables and graphs based on them, calculating statistical indices and evaluating them. A total of 7 statistical parameters were involved, namely systematic error (bias), mean absolute error (eT), mean quadratic error (sound), Pearson correlation coefficient (r), factor 2 (FA2), factor 5 (FA5), Index of Agreement (IOA).

The calculation of statistical parameters was carried out both for individual cases of very heavy precipitation and for daily precipitation totals. In both cases, unsatisfactory results were obtained. Statistical links between satellite and ground data series are insignificant, IMERG data, when assessing individual events of very heavy precipitation over the flat territories of Ukraine, demonstrate significant errors, which can be caused both by a discrepancy between the data itself for this kind of use, and by a shift in terms of coordinates, as well as time of data collection. Therefore, additional research is needed, the search for new and improvement of the proposed methodological approaches to the analysis of satellite information.

Keywords: heavy precipitation, GPM IMERG, verification, statistical parameters and indices.

Надійшла до редколегії 07.07.2021

\author{
DOI: https://doi.org/10.17721/2306-5680.2021.3.6 \\ УДК 551.574 .42
}

Пясецька С.I.

Український гідрометеорологічний інститут ДСНС України та НАН України, м. Київ

\section{ТЕНДЕНЦІЇ У РОЗПОВСЮДЖЕННЯ ВІДКЛАДЕНЬ ПАМОРОЗІ КАТЕГОРІЇ НЯ (небезПечна) НА ТЕРИТОРІЇ УКРАЇНИ ПРОТЯГОМ ОСТАННЬОГО ТРИДЦЯТИРІЧЧЯ 1991-2020 рр.}

Стаття присвячена дослідженню просторово-часового розповсюдження відкладень паморозі категорії НЯ (небезпечна) по території України у продовж останніх 30-и років, які характеризують сучасний стан та динаміку кліматичної системи в Україні та ії окремих елементів. Метою дослідження було встановити особливості просторово-часового розповсюдження таких відкладень по областям України по окремим десятиріччям досліджуваного періоду та окреслити тенденцію у їх розповсюдженні.. Доведено переважання випадків таких відкладень у січні та грудні протягом 1991-2000 рр. Проте помічено певна тенденція у наступному десятиріччі до деякого збільшення випадків таких відкладень у окремих місяцях перехідних сезонів року. Для останнього десятиріччя помічено зростання таких випадків у січні та грудні порівняно із попередніми десятиріччями. Проте протягом останніх 2-х років кількість випадків відкладень паморозі категорії НЯ дещо зменшилась. Доведено, що переважна більшість таких випадків спостерігалась на Закарпатті на метеорологічній станції Плай, що пов'язане із більшою частотою появи сприятливих умов для ї̈ утворення.

Ключові слова: відкладення паморозі категорії НЯ (небезпечна), стандартний ожеледний станок, розповсюдження відкладень паморозі категорії НЯ по території України, сучасні зміни клімату.

Вступ. Розповсюдження відкладень паморозі, як зернистої так і кристалічної на території України протягом зимового періоду та у перехідні сезони року $є$ поширеним явищем. Такі відкладення спостерігаються практично на усіх метеорологічних станціях країни причому найбільш часто в регіонах зі складною ландшафтною структурою. Серед таких відкладень трапляються випадки відкладень паморозі категорії НЯ (небезпечна).

Під випадками відкладення паморозі категорії НЯ (небезпечна) розуміється відкладення паморозі (кристалічної та/або зернистої) на дротах стандартного ожеледного станка, який встановлений на кожній із метеорологічних станцій (МС)України, діаметром 50 та більше мм, причому із виміряного діаметру відкладення вилучається діаметр дроту у 5 мм, яким оснащено стандартний ожеледний станок. Зазвичай такі відкладення здебільшого 
спостерігаються у зимові місяці - січень, лютий, грудень. Проте, вони можуть виникати за певних сприятливих умов наприкінці весни та у передзимовий період. Найбільш сприятливими умовами для виникнення паморозі $\epsilon$ - для зернистої слабкі переохолоджені опади (мряка), або досить сильний туман при малих швидкостях вітру та температури близької до $0^{\circ} \mathrm{C}$, а для кристалічної необхідна значна вологість повітря для сублімації водяної пари при значно нижчій його температурі ближче до $-10{ }^{\circ} \mathrm{C}$ та при штилі. Істотно впливає на розмір відкладення час його наростання. Для зернистої паморозі суттєве значення має розмір часток вологи, найсприятливішими для ії̈ виникнення є більш мілкодисперсні частки вологи, а при їх збільшенні їх розміру при тих самих температурних умовах частіше виникає ожеледь (непрозора, або прозора). Непрозора ожеледь та зерниста паморозь один від одного відрізняються тим, що при надламі у відкладенні паморозі помітні мілкі кристалики льоду, яких немає у відкладенні ожеледі.

Вважається, що такі відкладення можуть перешкоджати безперебійній роботі ряду галузей економіки у першу чергу такі як енергетика, дротовий зв'язок, транспорт, що використовує енергію яка передається за допомогою дротів (електропоїзди залізниці приміського сполучення та міській комунальний транспорт). В окремих випадках при значному навантаженні таких відкладень та поєднанні їх дії з вітровим напором можуть бути пошкоджені окремі види обладнання, які чуттєві до такого впливу, що спричинить від'єднання споживачів від ресурсу. Дослідження проведено для двох десятиріч - кінця XX сторіччя 1991-2000 рр., початку XXI сторіччя та 2001-2010 рр., а також протягом сучасного періоду з 2011 по 2020 рр.

Огляд стану дослідження проблеми. Перші етапи досліджень умов виникнення ожеледо-паморозевих та фрізики цього процесу було проведено у середині 30-х років та у післявоєнні 40-і роки минулого сторіччя. Дослідження фізичних умов ожеледо-паморозевих відкладень на на більш-менш системній основі із залученням спостережень на окремих метеорологічних станціях та у лабораторних умовах на теренах європейської частини колишнього СРСР розпочалось у середині $30-\mathrm{x}$ років $\mathrm{XX}$ сторіччя. Результати таких досліджень було викладено у книзі Б.П. Вайнберга «Снег, иней, град, лед и ледники»(1936) [1], де подано фізичні основи утворення ряду ожеледо-паморозевих відкладень. Подальші дослідження з цього приводу та визначення характеристик фрізичного стану ожеледопаморозевих відкладень було продовжено Н. С. Муретовим (1945), В.В. Бургсдорфом та О.Г. Балабуєвим у 1947.р. На той час було вже було окреслено новий напрямок досліджень з цього напряму - визначення територіально-часової організації розповсюдження окремих видів таких відкладень. Спираючись на вже отримані та систематизовані результати у 50-х роках минулого сторіччя А.Д. Заморським [4], було узагальнено та описано умови виникнення таких відкладень із наведенням конкретних прикладів їх фрізико-географрічного розповсюдження по території європейської частини колишнього СРСР. 3 накопиченням результатів спостережень на мережі метеостанцій (розширення мережі та оснащення ожеледними станками) за такими відкладеннями розпочався наступний етап дослідження, а саме визначення просторово-часового розповсюдження таких відкладень з урахуванням типу ландшафтів. Такі дослідження було проведено під керівництвом О.М. Раєвського $(1953,1961,1963)[6-9]$, який виділив окремі типи рельєфу (7), що зумовили особливості просторово-часового розповсюдження окремих видів наземного зледеніння принаймні на території України. Розробки О.М. Раєвського неодноразово було використано у роботах В.Е. Бучинського (1966) [2] та А.В. Рудневою (1961) [10] здебільшого для території європейської частини Росії. Особлива увага при цьому приділялась не тільки самим ожеледо-паморозевим відкладенням, зокрема і паморозі, а й їх територіальному розподілу, частоті повторюваності на окремих територіях. Було встановлено, що найбільш часто паморозь спостерігається на навітрених схилах височин Середнє-Руської, та Приволжської, височинах Прибалтики, а також на Донецькому та Тиманському кряжах та підвищених вододілах річок. Було встановлено значну мінливість таких відкладень по території навіть відносно однорідної за своїм складом. У 1971 р. накопичені матеріали та результати попередніх досліджень були викладені у монографії Е.П. Драневич [3]. У цій роботі було на ряду із визначеннями видів відкладень льоду, аналізом видів наземного зледеніння та матеріалами 3 районування північного заходу Європейської частини території СРСР(територія Кольського півострова, Ленінградська область, центральна частина Росії) ISSN:2306-5680 Hydrology, Hydrochemistry and Hydroecology. 2021. № 3 (61) 
відносно окремих видів ожеледо-паморозевих відкладень подано основи прогнозу відкладень ожеледі та паморозі в залежності від стану атмосфери та синоптичних умов, що складаються. Згідно до [3, 11,12] для синоптичних передумов утворення зернистої паморозі необхідний осередок або гребінь тепла та вологи, а також передня межа фронтальної зони, яка спостерігається на карті АТ-850 Гпа (тилова частина улоговини холоду), де спостерігається підвищення температури повітря, що пов'язане з наближенням теплого фрронту (наявність радіаційного охолодження у поверхні землі, інверсія або ізотермія, швидкість вітру у приземному шарі повітря 2-9 м/с, переважаюче баричне поле - гребені та улоговини, що переміщуються, теплі сектори циклонів). Для утворення кристалічної паморозі синоптичні передумови відрізняються від зернистої. Тут необхідні осередки та улоговини холоду на карті АТ-850 Гпа (радіаційне охолодження повітря або адвекція холоду при швидкостях вітру у землі 0-7 м/с). Крім того кристалічна паморозь може виникнути у малорухомих циклонічних областях, що заповнюються. При цьому найбільш сприятливими $€$ низини та територія поблизу водойм. Крім того досить часто умови виникнення зернистої паморозі можуть чергуватись з умовами виникнення кристалічної, особливо при швидких змінах синоптичної ситуації. Це чергування найбільш часто трапляється - відкладення зернистої паморозі чергуються із відкладеннями кристалічної.

На тепер для проведення стандартних спостережень на метеорологічних станціях, для узагальнення результатів спостережень, а також прогнозування окремих видів наземного зледеніння використовують ряд нормативних документів, а саме - оновлену редакцію «Настанови...» [14], щодо регламенту проведення спостережень на мережі станцій і постів, а для створення баз даних та опрацювання матеріалів спостережень за ожеледо-паморозевими відкладеннями, які проводяться на Державній мережі гідрометеорологічних спостережень використовують матеріали $[13,15,16]$. У цих «Настановах...» та «Роз'ясненнях...» подано критерії визначення стану небезпеки ряду метеорологічних явищ, зокрема і ожеледо-паморозевих. Так, згідно до них, до небезпечних явищ (НЯ) відносять відкладення паморозі, які становили на дротах стандарного ожеледного станка 50 та більше міліметрів, причому з діаметра відкладення вилучено діаметр дроту (на стандартному ожеледному станку діаметр дроту становить 5 мм, за відсутності такого дроту в окремих випадках допускається діаметр 4 або 6 мм про що повідомляється у матеріалах спостережень). Згідно до нових Керівних документів $[15,16]$ які нещодавно було прийнято в оперативну практику $(2018,2019$ рр.) у зв'язку зі змінами та імплементації нових положень у оперативній роботі, такі відкладення паморозі відносять до МЯ I (до метеорологічних явищ I-III рівнів небезпеки відносять явища погоди, які по досягненню визначених критеріїв можуть становити загрозу для життя та здоров'я людини та впливати на фрункціонування господарського комплексу країни). Натепер для оформлення попереджень та оперативних інформацій щодо виникнення небезпечних та стихійних явищ погоди на території України у мережі гідрометеорологічних організацій та служб ДСНС використовують кольорове позначення загрози. Так, для відкладення паморозі категорії НЯ (НМЯ I) використовують жовтий колір, куди віднесено вищезгадані відкладення паморозі. Крім того для наукових досліджень можна також використовувати матеріали викладені у інструкції [5] для організації роботи відділень залізниці у зимовий період та перешкоджання виникненню аварійних ситуацій.

Мета, об'єкт та предмет дослідження. Зважаючи на істотні зміни, які останнім часом відбуваються у світовій кліматичній системі та зокрема на території України, а також їх прискорення у часі та набуття ними певних загроз для суспільства, актуальним є всебічне дослідження природних погодних явищ, які можуть представляти небезпеку для господарської діяльності, зокрема протягом холодного періоду року (ожеледо-паморозеві явища). Тому, метою даного дослідження $є$ вивчення розподілу відкладень паморозі категорії НЯ на території України протягом останніх 30 років, які охоплюють сучасний стан кліматичної системи в країні, а останні 10 з них відображають поточні тенденції у змінах клімату зважаючи на постійний ріст глобальної температури повітря. Об'єктом дослідження стали випадки відкладень паморозі категорії НЯ протягом окремих десятиріч 1991-2000, 2001-2010 та 2011-2020 рр. Предметом - їх просторово-часове розповсюдження на території України протягом місяців та років цього 30-и річчя. 
Характеристика використаного матеріалу. Методи дослідження. Для дослідження було використано матеріали спостережень за ожеледо-паморозевими явищами на стандартному ожеледному станку на усіх метеорологічних станціях (МС) України протягом 7 місяців - січня, лютого, березня, квітня, жовтня, листопада та грудня протягом 1961-1990 рр. Ці матеріали розміщені у відповідних таблицях Метеорологічних щомісячників (Вип. 10 (Україна), Ч.ІІ ), які знаходяться у Державному галузевому архіві (ГДА) Центральної геофізичної обсерваторії імені Бориса Срезневського (ЦГО) у м. Києві, яка підпорядковується ДСНС України. Використовувались методи математичної статистики для визначення повторюваності випадків відкладень паморозі категорії НЯ по території України із подальшою візуалізацією у вигляді таблиць та графріків.

Виклад основного матеріалу дослідження. Виклад основного матеріалу здійснювався поетапно у 3-х розділах по кожному десятирічному періоду окремо та ілюструвався відповідними таблицями та рисунками.

1. Період 1991-2000 рр. Протягом цього десятиріччя такі відкладення неодноразово спостерігались на території України, що загалом становило 70 випадків (рис. 1а).

a

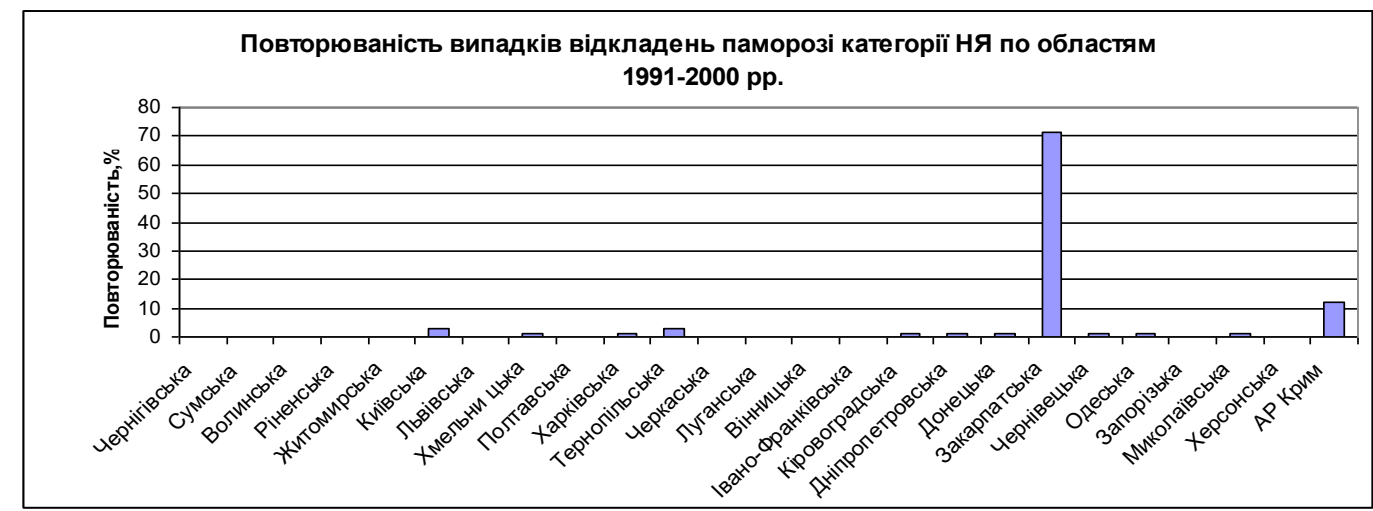

б

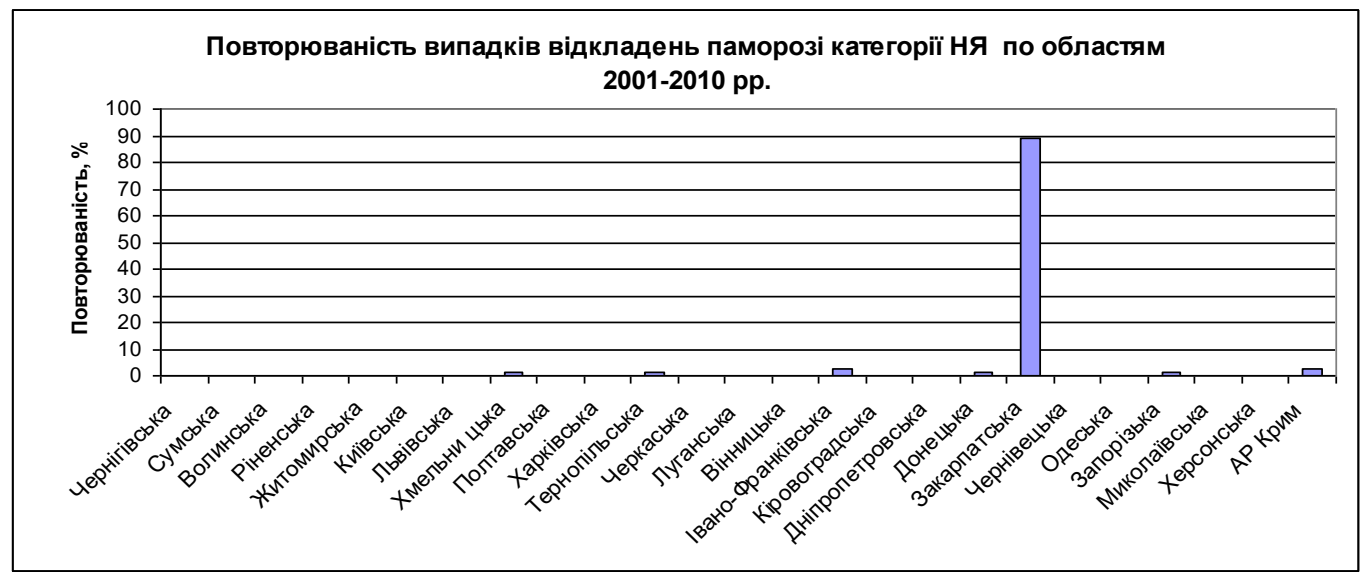

B

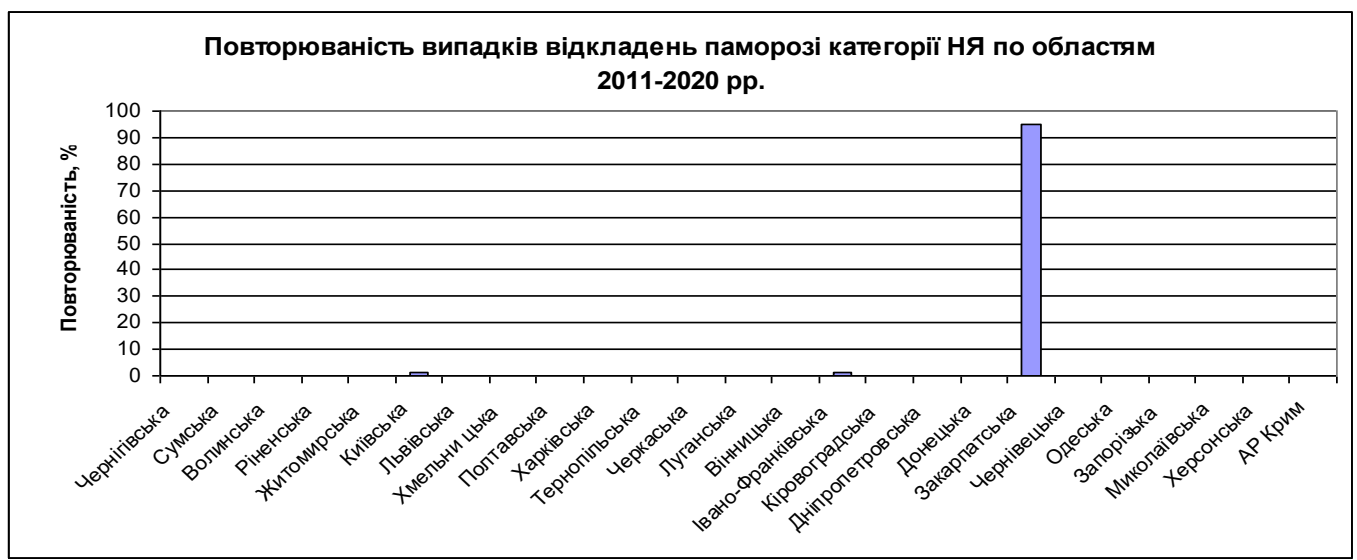

Рис.1. Повторюваність кількості відкладень паморозі категорії НЯ по окремих областях України протягом десятиріч: а) 1991-2000; б) 2001-2010; в) 2011-2020 рр.

ISSN:2306-5680 Hydrology, Hydrochemistry and Hydroecology. 2021. № 3 (61) 
Вони спостерігались майже на половині областей України на території 12 областей на 14 станціях. А саме - Закарпатської (Плай), Хмельницької (Ямпіль), Тернопільська (Тернопіль, Чортків), Чернівецької (Новодністровськ), Київської (Біла Церква, Чорнобиль), Харківської (Великий Бурлук), Донецької (Дебальцеве), Кіровоградської (Долинська), Дніпропетровської (Синельнікове), Одеської (Любашівка), Миколаївської (Баштанка), АР Крим (Ай-Петрі). Не спостерігались вони у 13 областях - Чернігівській, Сумській, Волинській, Івано-Франківській, Львівській, Рівненській, Житомирській, Полтавській, Черкаській, Луганській, Вінницькій, Запорізькій та Херсонській областях, що ілюструє (рис. 1а). Найбільш часто такі відкладення спостерігались у січні - 24 випадки (34,3 \%), лютому - 14 випадків $(20,0 \%)$ та у грудні - 16 випадків (22,9 \%). Внесок інших місяців у загальну кількість таких випадків протягом 1991-2000рр. був незначний - у березні 7,1 \%, квітні 1,4 \%, жовтні 2,9 \%, листопаді 11,4 \%. Такий просторово-часовий розподіл відкладень паморозі категорії НЯ відображено у таблиці 1.

Таблиця 1. Повторюваність (\%) випадків відкладень паморозі категорії НЯ (небезпечна) на території України по окремих областях протягом 1991-2000 рр.

\begin{tabular}{|c|c|c|c|c|c|c|c|c|c|}
\hline \multirow[t]{2}{*}{ Області } & \multicolumn{7}{|c|}{ Місяці } & \multirow[t]{2}{*}{ Усього } & \multirow{2}{*}{$\begin{array}{l}\text { Повторю- } \\
\text { ваність, \% }\end{array}$} \\
\hline & I & II & III & IV & $\mathbf{X}$ & $\mathbf{X I}$ & XII & & \\
\hline \multicolumn{10}{|l|}{ Чернігівська } \\
\hline \multicolumn{10}{|l|}{ Сумська } \\
\hline \multicolumn{10}{|l|}{ Волинська } \\
\hline \multicolumn{10}{|l|}{ Рівненська } \\
\hline \multicolumn{10}{|l|}{ Житомирська } \\
\hline Київська & & & & & & & 2 & 2 & 2,9 \\
\hline \multicolumn{10}{|l|}{ Львівська } \\
\hline Хмельницька & 1 & & & & & & & 1 & 1,4 \\
\hline \multicolumn{10}{|l|}{ Полтавська } \\
\hline Харківська & & & & & & & 1 & 1 & 1,4 \\
\hline Тернопільська & 2 & & & & & & & 2 & 2,9 \\
\hline \multicolumn{10}{|l|}{ Черкаська } \\
\hline \multicolumn{10}{|l|}{ Луганська } \\
\hline \multicolumn{10}{|l|}{ Вінницька } \\
\hline \multicolumn{10}{|l|}{ Івано-Франківська } \\
\hline Кіровоградська & 1 & & & & & & & 1 & 1,4 \\
\hline Дніпропетровська & 1 & & & & & & & 1 & 2,9 \\
\hline Донецька & & & & & & & 1 & 1 & 1,4 \\
\hline Закарпатська & 11 & 13 & 4 & 1 & 2 & 8 & 11 & 50 & 71,4 \\
\hline Чернівецька & 1 & & & & & & & 1 & 1,4 \\
\hline Одеська & 1 & & & & & & & 1 & 1,4 \\
\hline \multicolumn{10}{|l|}{ Запорізька } \\
\hline Миколаївська & 1 & & & & & & & 1 & 1,4 \\
\hline \multicolumn{10}{|l|}{ Херсонська } \\
\hline АР Крим & 5 & 1 & 1 & & & & 1 & 8 & 11,8 \\
\hline Усього & 24 & 14 & 5 & 1 & 2 & 8 & 16 & 70 & 100,0 \\
\hline Повторюваність, \% & 34,3 & 20,0 & 7,1 & 1,4 & 2,9 & 11,4 & 22,9 & 100,0 & \\
\hline
\end{tabular}

Січень. Відкладення паморозі категорії НЯ спостерігалось на території України майже кожного року за виключенням 1996 р. Їх загальна кількість становила 24 випадки, які спостерігались у 9 областях на 10 станціях - Закарпатській (Плай), Хмельницькій (Ямпіль), Тернопільській (Тернопіль, Чортків), Чернівецькій (Новодністровськ), Одеській (Любашівка), Кіровоградській (Долинська), Миколаївській (Баштанка),Дніпропетровській (Синельнікове) та АР Крим (Ай-Петрі). Здебільшого у областях була лише одна станція, яка спостерігала такі відкладення за виключенням Тернопільської області, де таких станцій було 2. Тобто, переважно у областях такі відкладення були поодинокі (1-2 випадки), тому їх внесок становив 4,2 та 8,3 \% від загалу. Саме така кількість випадків спостерігались у Хмельницькій, Тернопільській, Кіровоградській, Дніпропетровській, Чернівецькій та Одеській областях. Проте на Закарпатті (МС Плай) та у АР Крим (Ай-Петрі) їх було значно 
більше, відповідно 11 та 5 випадків, що становило 45,8 та 20,8 \% від загалу за цей місяць протягом першого десятиріччя загального досліджуваного періоду 1991-2000рр. По окремих роках найбільше таких випадків спостерігалось у 1992 та 1999 рр., що становило відповідно 6 та 7 випадків, або 25,0 та 29,2 \% від загалу за цей місяць. Розподіл кількості випадків таких відкладень по окремих роках цього десятиріччя ілюструє таблиця 4.

Лютий. У цей період відкладення паморозі категорії НЯ спостерігались лише на території 2-х областей - Закарпатської (Плай) та АР Крим (Ай-Петрі), загальною кількістю 14 випадків (табл.1). Такі відкладення на території України спостерігались майже кожного року за виключенням 1995, 1997 та 1998 рр. (табл. 4). Здебільшого вони були поодинокими 1-2 випадки, але у 1993 р. на МС Плай їх спостерігалось 3 випадки $(21,4$ \%). Загалом на МС Плай протягом лютого 1991-2000 рр. встановлено 13 випадків відкладень паморозі категорії НЯ, що складає 92,9 \% від загальної кількості таких відкладень за цей період та свідчить про перевагу цієї станції у внесок до загалу.

Березень. У березні протягом 1991-2000 рр. на території України, так само як і у лютому відкладення паморозі категорії НЯ спостерігались на території 2-х областей Закарпатській (Плай), та АР Крим (Ай-Петрі) загальною кількістю 5 випадків (табл.1). Загалом на Закарпатську область та МС Плай припало 80,0 \% випадків відкладень паморозі категорії НЯ протягом 1991-2000 рр., а на АР Крим та Ай-Петрі 20,0 \%. По роках періоду вони спостерігались лише у 1995, 1998 та 2000 р., в решті років вони не спостерігались (табл. 4). У 1995 та 1998 рр. таких випадків було 2, що відповідно становило 40,0\% у кожному з них, і усі вони спостерігались на МС Плай.

Квітень. У квітні цього досліджуваного десятиріччя випадки відкладень паморозі категорії НЯ спостерігались виключно та території Закарпатської області на МС Плай. Таких випадків було лише 1 у 1997 р. Внесок цього місяця у загальну кількість випадків відкладень паморозі категорії НЯ у загальну кількість за 1991-2000 рр. найменший - 1,4%. На решті території таких випадків відкладень не спостерігалось (табл.4).

Жовтень. У цьому місяці відкладення паморозі категорії НЯ на території України спостерігались лише на Закарпатті на МС Плай у кількості 2-х випадків. Внесок у загальну кількість таких випадків протягом 1991-2000 рр. становив 2,9 \% від загалу (табл.1). По окремих роках десятиріччя вони спостерігались відповідно по одному у 1991 та 1999 рр. (табл.4).

Листопад. У листопаді так само як і у квітні та жовтні такі відкладення спостерігались лише на Закарпатті на МС Плай загальною кількістю 8 випадків, що становило 11,4 \% від загалу за це десятиріччя (табл.1). По роках періоду такі відкладення спостерігались у 19921996, 1998 та 1999 рр., що ілюструє (табл. 4).

Грудень. У грудні цього періоду відкладення паморозі категорії НЯ спостерігались на території 5 областей на 6 станціях - Закарпатської (Плай), Київської (Біла Церква, Чорнобиль), Харківської (Великий Бурлук), Донецької (Дебальцеве) та Ар Крим (Ай-Петрі) загальною кількістю 16 випадків, або 22,9 \% від загалу (табл. 1). Здебільшого такі випадки по областях були поодинокі 1-2 випадки, але на Закарпатті на МС Плай їх було 11 випадків, що склало 68,8 \%. Вони спостерігались не кожного року а лише у 1991-1994, 1997-1999 рр. (табл.4.)

2. Період 2001-2010 рр. Загалом за досліджуваний період спостерігалось 72 випадки відкладень паморозі категорії НЯ на території України. Протягом цього періоду вони спостерігались на території 7 областей на 7 станціях - Хмельницької (Хмельницький), Тернопільської (Тернопіль), Закарпатської (Плай), Донецької (Дебальцеве), ІваноФранківської (Пожежевська), Запорізької (Пришиб) та АР Крим (Ай-Петрі). Територіальний розподіл таких випадків по окремих областях України показано на рис. 1б. Їх повторюваність по окремих місяцях досліджуваного періоду відображає таблиця 2. Встановлено, що як і зазвичай такі відкладення найчастіше спостерігались у січні - 15 випадків або 20,8 \% від загалу за досліджуваний період та у грудні - 17 випадків (23,6 \%). На лютий, березень та листопад за цей проміжок часу припадало по 12 випадків, що склало 16,7 \% на кожний з цих місяців від загалу. У квітні та жовтні такі відкладення були поодинокі, у квітні спостерігалось 3 випадки, а у жовтні лише 1 випадок. Треба зауважити, що при цьому у ці місяці випадки відкладень паморозі категорії НЯ спостерігались лише на Закарпатті на МС Плай. По окремих областях найбільший внесок за цей період у загальну кількість випадків ISSN:2306-5680 Hydrology, Hydrochemistry and Hydroecology. 2021. № 3 (61) 
із відкладеннями паморозі категорії НЯ має Закарпатська область та МС Плай. Ïх внесок становить 88,9 \% у загальну кількість випадків протягом 2001-2010рр. Треба зазначити, що такі відкладення були більш поширені територією України у січні, ніж у інші з досліджуваних місяців. Порівняно із 1991-2000 рр. у цьому періоді майже на половину зменшилась фактична кількість випадків паморозі категорії НЯ у січні та на кілька значень у лютому. Проте, їх кількість зросла більше ніж у двічі у березні та дещо менше у листопаді. У квітні та жовтні зміни у кількості таких випадків були незначні.

Таблиця 2. Повторюваність (\%) випадків відкладень паморозі категорії НЯ (небезпечна) на території України по окремих областях протягом 2001-2010 рр.

\begin{tabular}{|c|c|c|c|c|c|c|c|c|c|}
\hline \multirow{2}{*}{ Області } & \multicolumn{7}{|c|}{ Місяці } & \multirow{2}{*}{ Усього } & \multirow{2}{*}{$\begin{array}{l}\text { Повторю- } \\
\text { ваність, \% }\end{array}$} \\
\hline & I & II & III & IV & $\mathbf{X}$ & $\mathbf{X I}$ & XII & & \\
\hline \multicolumn{10}{|l|}{ Чернігівська } \\
\hline \multicolumn{10}{|l|}{ Сумська } \\
\hline \multicolumn{10}{|l|}{ Волинська } \\
\hline \multicolumn{10}{|l|}{ Рівненська } \\
\hline \multicolumn{10}{|l|}{ Житомирська } \\
\hline \multicolumn{10}{|l|}{ Київська } \\
\hline \multirow{2}{*}{\multicolumn{10}{|c|}{ Львівська }} \\
\hline & & & & & & & & & 1,4 \\
\hline \multicolumn{10}{|l|}{ Полтавська } \\
\hline \multicolumn{10}{|l|}{ Харківська } \\
\hline Тернопільська & 1 & & & & & & & 1 & 1,4 \\
\hline \multicolumn{10}{|l|}{ Черкаська } \\
\hline \multicolumn{10}{|l|}{ Луганська } \\
\hline \multicolumn{10}{|l|}{ Вінницька } \\
\hline Івано-Франківська & 1 & & & & & & 1 & 2 & 2,8 \\
\hline \multicolumn{10}{|l|}{ Кіровоградська } \\
\hline \multicolumn{10}{|l|}{ Дніпропетровська } \\
\hline Донецька & 1 & & & & & & & 1 & 1,4 \\
\hline Закарпатська & 10 & 11 & 12 & 3 & 1 & 12 & 15 & 64 & 88,9 \\
\hline \multicolumn{10}{|l|}{ Чернівецька } \\
\hline \multicolumn{10}{|l|}{ Одеська } \\
\hline Запорізька & 1 & & & & & & & 1 & 1,4 \\
\hline \multicolumn{10}{|l|}{ Миколаївська } \\
\hline \multicolumn{10}{|l|}{ Херсонська } \\
\hline АР Крим & & 1 & & & & & 1 & 2 & 2,8 \\
\hline Усього & 15 & 12 & 12 & 3 & 1 & 12 & 17 & 72 & 100,0 \\
\hline Повторюваність,\% & 20,8 & 16,7 & 16,7 & 4,2 & 1,4 & 16,7 & 23,6 & 100,0 & \\
\hline
\end{tabular}

Січень. У січні цього періоду загальна кількість випадків відкладень паморозі категорії Настановила 15 випадків, які спостерігались на території 6 областей на 6 станціях Хмельницькій (Хмельницький), Тернопільській (Тернопіль), Івано-Франківській (Пожежевська), Закарпатській (Плай), Донецькій (Дебальцеве),Запорізькій (Пришиб). Враховуючи окремі станції, які спостерігали такі відкладення, найбільша їх кількість спостерігалась на МС Плай та становила 10 випадків, або 66,7 \% від загалу у цьому місяці. На решту станцій припадає по 1 випадку на кожну, що становить 6,7 \%. Таблиця 5 ілюструє ситуацію із розподілом таких відкладень по окремих роках досліджуваного періоду. Так, такі відкладення мали місце у 2002-2006, 2009 та 2010 рр., тобто у 3-х роках 2001, 2007 та 2008 вони на території України не спостерігались. Здебільшого випадки відкладень паморозі категорії НЯ спостерігались поодиноко, але їх найбільша кількість спостерігалась у 2002, 2005 та 2010 рр. і становила 3 випадки у кожному з цих років.

Лютий. Відкладення паморозі категорії НЯ у цей час спостерігались лише на території 2-х областей - на Закарпатті на МС Плай та у АР Крим на Ай-Петрі. Загальна кількість подібних випадків склала 12, що становило 16,7 \% від їх загальної кількості за цей період (табл.2). Внесок цих двох областей становив 91,7 \% для Закарпаття та 8,3 \% для Ар Крим. 
По окремих роках періоду такі відкладення спостерігались у 2001, 2003, 2005-2009 рр. (табл. 5).

Березень. У березні 2001-2010 рр. відкладення паморозі категорії НЯ спостерігались виключно на території Закарпатської області на МС Плай. Усього було встановлено 12 подібних випадків, що я і у лютому становило 16,7 \%. По окремих роках цього десятиріччя вони спостерігались у 2003 та 2005-2010 рр. Найбільша їх кількість 4 випадки спостерігалась у 2009 р., що склало 33,3 \% від загалу за цей місяць протягом 2001-2010 рр.(табл.5).

Квітень. У квітні досліджуваного десятиряччя такі відкладення паморозі, як і у березні спостерігались лише на Закарпатті на МС Плай загальною кількістю 3 випадки за досліджуване десятиріччя, що становило 4,2 \% від загалу за цей період (табл.2). По окремих роках періоду вони були поодинокі та спостерігались лише у 2005, 2006 та 2008 рр., про що свідчить табл. 5.

Жовтень. У цьому місяці такі відкладення так само як у березні та квітні спостерігались лише у Закарпатській області на МС Плай кількістю 1 випадок або 1,4 \% від загалу за десятиріччя (табл 2). Цей випадок спостерігався у 2005 р.

Листопад. Спостерігається тенденція, що протягом березня, квітня та у листопаді 2001-2010 рр. відкладення паморозі категорії НЯ спостерігались тільки на Закарпатті на МС Плай загальною кількістю 12 випадків, або 16,7 \% від загалу (табл. 2). По окремих роках досліджуваного періоду вони спостерігались у 2001, 2002, 2005-2008, 2010 рр.(табл.5). Здебільшого такі відкладення були поодинокі, проте у 2007 та 2010 рр. таких випадків було по 3 у кожному з вищезгаданих років, що становило відповідно по 25,0 \% кожний.

Грудень. У грудні цього десятиріччя відкладення паморозі категорії НЯ спостерігались на території 3 областей - Закарпатської (Плай), Івано-Франківської (Пожежевська) та АР Крим (Ай-Петрі). Загальна кількість випадків таких випадків становила 17, що склало 23,6 \% від загальної кількості за десятиріччя (табл.2). Такі відкладення спостерігались майже кожного року за виключенням таких років, як 2001, 2009 та 2010 рр. (табл.5). Найбільша кількість випадків припала на 2004, 2005, 2007 рр. - відповідно 3 та по 4 випадки що склала відповідно 17,6 \% для 2004 р. та по 23,5 \% у 2005 та 2007 рр.

3. Період 2011-2020 рр. Цей період відображає поточну тенденцію та сучасний стан просторово-часового розповсюдження відкладень паморозі категорії НЯ. 3'ясовано, що такі відкладення спостерігались переважно на території Закарпатської області на МС Плай. Лише кілька випадків таких відкладень, а саме - 1 випадок таких відкладень у січні зареєстровано у Київській області на МС Баришівка та ще 1 у березні на МС Пожежевська (Івано-Франківщина) що відображено на рис.1 в. Загальна кількість таких відкладень за цей період становила 76 випадків, причому 74 з них на МС Плай, що дещо більше ніж загалом випадків таких відкладень у протягом 1991-2000 рр., або 2001-2010 рр. (відповідно 70 та 72 випадки). На відміну від попередніх досліджуваних десятиріч, по окремих місяцях 2011-2020 рр. випадки відкладень паморозі категорії НЯ спостерігались у січні - квітні, листопаді та грудні, проте у жовтні цього періоду вони не спостерігались (табл. 3). Звертає на себе увагу те, що у окремі місяці існує певний перерозподіл кількості випадків відкладень паморозі категорії НЯ на території України, порівняно із попередніми десятиріччями. Так, наприклад, їх кількість зросла у січні особливо порівняно із 2001-2010 рр., проте дещо зменшилась у грудні порівняно із двома попередніми десятиріччями (табл. 3). Також у квітні продовжувала існувати тенденція до зменшення таких випадків, зокрема і в Карпатському регіоні, а у жовтні на відміну від двох попередніх десятиріч таких випадків зовсім не спостерігалось.

Січень. У січні цього десятирічного періоду відкладення паморозі категорії НЯ спостерігались у тій чи іншій кількості кожного року, причому майже усі випадки спостерігались на Закарпатті на МС Плай - 26 випадів або 96,3 \% від загалу за цей місяць (табл. 3). Загалом таких випадків було 27 (35,5 \%). Лише 1 випадок таких відкладень було встановлено на території Київської області у Баришивці у 2018 р. По окремих роках найбільша кількість випадків із такими відкладеннями спостерігалась у 2011,2015, 2018 рр. та 2020 рр., а саме у 2011, 2015 та 2020 - 4 випадки, або 14,8 \% від загалу у цьому місяці та у 2018 р. - 5 випадків, або 18,5 \% (табл.6). 
Таблиця 3. Повторюваність (\%) випадків відкладень паморозі категорії НЯ (небезпечна) на території України по окремих областях протягом 2011-2020 рр.

\begin{tabular}{|c|c|c|c|c|c|c|c|c|c|}
\hline \multirow{2}{*}{ Області } & \multicolumn{7}{|c|}{ Місяці } & \multirow{2}{*}{ Усього } & \multirow{2}{*}{$\begin{array}{l}\text { Повторю- } \\
\text { ваність, \% }\end{array}$} \\
\hline & I & II & III & IV & $\mathbf{X}$ & $\mathbf{X I}$ & XII & & \\
\hline \multicolumn{10}{|l|}{ Чернігівська } \\
\hline \multicolumn{10}{|l|}{ Сумська } \\
\hline \multicolumn{10}{|l|}{ Волинська } \\
\hline \multirow{2}{*}{\multicolumn{10}{|c|}{$\begin{array}{l}\text { Рівненська } \\
\text { Житомирська }\end{array}$}} \\
\hline & & & & & & & \multicolumn{3}{|c|}{ Житомирська } \\
\hline Київська & 1 & & & & & & & 1 & 1,3 \\
\hline \multicolumn{10}{|l|}{ Львівська } \\
\hline \multicolumn{10}{|l|}{ Хмельницька } \\
\hline \multicolumn{10}{|l|}{ Полтавська } \\
\hline \multicolumn{10}{|l|}{ Харківська } \\
\hline \multirow{2}{*}{\multicolumn{10}{|c|}{$\begin{array}{l}\text { Тернопільська } \\
\text { Черкаська }\end{array}$}} \\
\hline & & & & & & & & & \\
\hline \multicolumn{10}{|l|}{ Луганська } \\
\hline \multicolumn{10}{|l|}{ Вінницька } \\
\hline Івано-Франківська & & & 1 & & & & & 1 & 1,3 \\
\hline \multicolumn{10}{|l|}{ Кіровоградська } \\
\hline \multicolumn{10}{|l|}{ Дніпропетровська } \\
\hline \multicolumn{10}{|l|}{ Донецька } \\
\hline Закарпатська & 26 & 13 & 9 & 2 & 0 & 9 & 13 & 72 & 94,7 \\
\hline \multicolumn{10}{|l|}{ Чернівецька } \\
\hline \multicolumn{10}{|l|}{ Одеська } \\
\hline \multicolumn{10}{|l|}{ Запорізька } \\
\hline \multicolumn{10}{|l|}{ Миколаївська } \\
\hline \multirow{2}{*}{\multicolumn{10}{|c|}{$\begin{array}{l}\text { Херсонська } \\
\text { АР Крим }\end{array}$}} \\
\hline & & & & & & & & & \\
\hline Усього & 27 & 15 & 10 & 2 & 0 & 9 & 13 & 76 & 100,0 \\
\hline Повторюваність,\% & 35,5 & 19,7 & 13,2 & 2,6 & 0,0 & 11,8 & 17,1 & 100,0 & \\
\hline
\end{tabular}

Таблиця 4. Повторюваність випадків відкладення паморозі НЯ (небезпечна) по окремих місяцях протягом окремих років періоду 1991-2000 pp.

\begin{tabular}{|l|c|c|c|c|c|c|c|c|c|c|c|}
\hline Місяці & $\mathbf{1 9 9 1}$ & $\mathbf{1 9 9 2}$ & $\mathbf{1 9 9 3}$ & $\mathbf{1 9 9 4}$ & $\mathbf{1 9 9 5}$ & $\mathbf{1 9 9 6}$ & $\mathbf{1 9 9 7}$ & $\mathbf{1 9 9 8}$ & $\mathbf{1 9 9 9}$ & $\mathbf{2 0 0 0}$ & Усього \\
\hline $\mathrm{I}$ & 1 & 6 & 1 & 2 & 2 & 0 & 1 & 1 & 7 & 3 & 24 \\
\hline $\mathrm{II}$ & 1 & 2 & 3 & 2 & 0 & 2 & 0 & 0 & 2 & 2 & 14 \\
\hline $\mathrm{III}$ & 0 & 0 & 0 & 0 & 2 & 0 & 0 & 2 & 0 & 0 & 5 \\
\hline $\mathrm{IV}$ & 0 & 0 & 0 & 0 & 0 & 0 & 1 & 0 & 0 & 0 & 1 \\
\hline $\mathrm{X}$ & 1 & 0 & 0 & 0 & 0 & 0 & 0 & 0 & 1 & 0 & 2 \\
\hline $\mathrm{XI}$ & 0 & 1 & 1 & 1 & 2 & 1 & 0 & 1 & 1 & 0 & 8 \\
\hline XII & 4 & 2 & 3 & 2 & 0 & 0 & 3 & 1 & 1 & 0 & 16 \\
\hline Усього & 7 & 11 & 8 & 7 & 6 & 3 & 4 & 5 & 10 & 5 & 70 \\
\hline
\end{tabular}

Таблиця 5. Повторюваність випадків відкладення паморозі НЯ (небезпечна) по окремих місяцях протягом окремих років періоду 2001-2010 pp.

\begin{tabular}{|l|c|c|c|c|c|c|c|c|c|c|c|}
\hline Місяці & $\mathbf{2 0 0 1}$ & $\mathbf{2 0 0 2}$ & $\mathbf{2 0 0 3}$ & $\mathbf{2 0 0 4}$ & $\mathbf{2 0 0 5}$ & $\mathbf{2 0 0 6}$ & $\mathbf{2 0 0 7}$ & $\mathbf{2 0 0 8}$ & $\mathbf{2 0 0 9}$ & $\mathbf{2 0 1 0}$ & Усього \\
\hline $\mathrm{I}$ & 0 & 3 & 1 & 1 & 3 & 2 & 0 & 0 & 2 & 3 & 15 \\
\hline $\mathrm{II}$ & 1 & 0 & 2 & 0 & 2 & 2 & 2 & 1 & 2 & 0 & 12 \\
\hline $\mathrm{III}$ & 0 & 0 & 1 & 0 & 1 & 3 & 1 & 1 & 4 & 1 & 12 \\
\hline $\mathrm{IV}$ & 0 & 0 & 0 & 0 & 1 & 1 & 0 & 1 & 0 & 0 & 3 \\
\hline $\mathrm{X}$ & 0 & 0 & 0 & 0 & 1 & 0 & 0 & 0 & 0 & 0 & 1 \\
\hline $\mathrm{XI}$ & 1 & 1 & 0 & 0 & 1 & 1 & 3 & 2 & 0 & 3 & 12 \\
\hline XII & 0 & 1 & 2 & 3 & 4 & 2 & 4 & 1 & 0 & 0 & 17 \\
\hline Усього & 2 & 5 & 6 & 4 & 13 & 11 & 10 & 6 & 8 & 7 & 72 \\
\hline
\end{tabular}


Таблиця 6. Повторюваність випадків відкладення паморозі НЯ (небезпечна) по окремих місяцях протягом окремих років періоду 2011-2020 рр.

\begin{tabular}{|l|c|c|c|c|c|c|c|c|c|c|c|}
\hline Місяці & $\mathbf{2 0 1 1}$ & $\mathbf{2 0 1 2}$ & $\mathbf{2 0 1 3}$ & $\mathbf{2 0 1 4}$ & $\mathbf{2 0 1 5}$ & $\mathbf{2 0 1 6}$ & $\mathbf{2 0 1 7}$ & $\mathbf{2 0 1 8}$ & $\mathbf{2 0 1 9}$ & $\mathbf{2 0 2 0}$ & Усього \\
\hline I & 4 & 1 & 2 & 2 & 4 & 1 & 3 & 5 & 1 & 4 & 27 \\
\hline II & 2 & 0 & 2 & 0 & 2 & 2 & 2 & 3 & 2 & 0 & 15 \\
\hline III & 2 & 0 & 2 & 2 & 1 & 0 & 2 & 0 & 0 & 1 & 10 \\
\hline IV & 0 & 1 & 0 & 0 & 0 & 1 & 0 & 0 & 0 & 0 & 2 \\
\hline X & 0 & 0 & 0 & 0 & 0 & 0 & 0 & 0 & 0 & 0 & 0 \\
\hline XI & 1 & 0 & 0 & 1 & 2 & 2 & 1 & 0 & 0 & 2 & 9 \\
\hline XII & 2 & 2 & 2 & 1 & 2 & 2 & 0 & 2 & 0 & 0 & 13 \\
\hline Усього & 11 & 4 & 8 & 6 & 11 & 8 & 8 & 10 & 3 & 7 & 76 \\
\hline
\end{tabular}

Лютий. У цьому місяці випадків відкладень паморозі категорії НЯ спостерігалось 15 випадків. Усі вони спостерігались виключно на МС Плай, що на Закарпатті. Внесок лютого у загальну кількість таких випадків за 2011-2020 рр. становив 19,7 \% (табл. 3). Випадки таких відкладень траплялись майже кожного року цього проміжку часу за виключенням 2012, 2014 та 2020 рр. коли вони не спостерігались на території України. По окремих роках найбільше таких випадків спостерігалось у 2018 р. - 3, що становило 20,0 \% від загалу за цей місяць (табл. 6).

Березень. У березні 2011-2020 рр. спостерігалось 10 випадків відкладень паморозі категорії НЯ, що становило 13,2 \% від загалу за досліджуваний період. 3 них 9 випадків спостерігалась на МС Плай на Закарпатті, що становило 90,0\% та 1 випадок $(10,0$ \%) у Івано-Франківській області на МС Пожежевська (табл.3). По окремих роках періоду такі відкладення спостерігались майже кожного року за виключенням 2012, 2016, 2018 та 2019 pp. Відкладення паморозі категорії НЯ були поодинокі, найбільша кількість їх в окремі роки становила 2 випадки (2011, 2013, 2014, 2017 рр.), що становило 20,0 \% у кожному з них від загальної кількості за цей місяць (табл.6).

Квітень. Протягом квітня 2011-2020 рр. випадки відкладень паморозі категорії НЯ були не чисельні - лише 2 випадки і тільки на Закарпатті на МС Плай (табл. 3). Вони спостерігались у 2-х роках - 2012 та 2016 (табл. 6).

Жовтень. У цьому місяці відкладень паморозі категорії НЯ на території України не спостерігалось.

Листопад. Протягом досліджуваного періоду на території України спостерігалось 9 випадків відкладень паморозі категорії НЯ, що становило 11,8 \% від загальної кількості за 2011-2020 рр. (табл.3). Усі вони спостерігались тільки в одному місці на Закарпатті на МС Плай. Такі відкладення відмічались у 2011, 2014-2017, 2020 рр. Найбільша кількість випадків таких відкладень - 2, відмічалась у 2015, 2016 та 2020 рр., що становило 22,2 \% відповідно (табл.6).

Грудень. Протягом грудня 2011-2020рр. відкладення паморозі категорії НЯ так само, як і у більшості досліджуваних місяців спостерігались на Закарпатті (Плай), загальною кількістю 13 випадків, або 17,1 \% від загалу за цей період. Вони спостерігались майже кожного року за виключенням 2017 та 2019, 2020 рр. У 2011-2013, 2015 та 2016 рр. кількість випадків становила по 2-а кожного року, що склало 15,4 \% для кожного з них (табл.6).

Висновки. Отже, зважаючи на отримані результати дослідження можна сказати, що у 1991-2000 рр. найбільша кількість випадків відкладень паморозі категорії НЯ на території України спостерігалась у січні, лютому та грудні, причому на січень припадає переважна кількість випадків.

Протягом січня відкладення паморозі категорії НЯ були достатньо широко представлені на території України у 9 областях. Протягом лютого та березня вони спостерігались лише у гірських місцевостях - на Закарпатті та у АР Крим. У квітні, жовтні та листопаді такі відкладення спостерігались лише на Закарпатті на метеостанції Плай. У грудні ареал їх поширення розширився і вони спостерігались не тільки у гірській місцевості, а й на півночі, північному сході та сході країни на території 5 областей.

Найбільша кількість таких випадків протягом 1991-2000рр. спостерігалась на Закарпатті (Плай) та у АР Крим (Ай-Петрі). 
У періоді 2001-2010 рр. також основна кількість випадків відкладення паморозі категорії НЯ припадає на місяці холодного періоду року, особливо січень та грудень. На відміну від періоду 1991-2000 рр. відбулось збільшення кількості випадків у березні та листопаді, а також дещо зросла кількість таких відкладень у квітні.

Переважна кількість випадків відкладень паморозі категорії НЯ протягом 2001-2010 pp. так само як і у попереднє десятиріччя спостерігалось на території Закарпаття на метеостанції Плай.

Протягом 2011-2020рр. помічено збільшення кількості випадків відкладень паморозі категорії НЯ у січні та лютому відносно 2001-2010 рр. та деяке зменшення цих відкладень у листопаді та грудні. На відміну від попередніх десятиріч у жовтні цього періоду відкладень паморозі категорії НЯ не спостерігалось. Також для цього періоду встановлено більшу локалізацію таких відкладень на Закарпатті в усіх досліджуваних місяців відносно попередніх досліджуваних періодів, коли особливо у січні та грудні такі відкладення були досить широко розповсюджені по території України. Одним з пояснень такого розподілу може слугувати триваюче потепління холодного періоду, яке спостерігається в Україні при якому сприятливі умови для виникнення таких відкладень спостерігаються переважно у гірських місцевостях.

\section{Список літератури}

1. Вайнберг Б.П. Снег, иней, град, лед и дедники. ОНТИ. М.-Л.: 231 с.

2. Бучинский В.Е. Атлас облединения проводов. Л.: Гидрометеоиздат. 1966.116 с.

3. Драневич Е.П. Гололед и изморозь. Условия образования, прогноз и гололедное районирование северо-запада Европейской территории СССР. Л.: Гидрометеоиздат, 1971. 228 с.

4. Заморский А.Д. Атмосферный лед. Иней, гололед, снег и град. М.-Л.: Изд-во Академии наук СCCP, 1955. 377 c.

5. Инструкция по подготовке к работе в зимний период и организации снегоборьбы на железных дорогах, в других фрилиалах и структурных подразделениях ОАО «РЖД», а также его дочерних и зависимых обществах. // Вагоны и вагонное хозяйство. 2014. №3. М.: Изд-во Российские железные дороги. С. 14-22. C. $28-31$.

6. Раєвський А.Н. К вопросу о повторяемоти гололеда. Метеорология и гидрология, 1953. №1.

7. Раевский А.Н. Влияние рельефа на распределение гололедно-изморозевых обложений. Труды ОГМИ. 1961. Вып. XXIII. С. 3-10.

8. Раевский А.Н. О распределении гололеда на территории Украины. Труды УкрНИГМИ. 1961. Вып. 29. С. 50-62.

9. Раевский А.Н. Влияние особенностей рельефа на распределение гололедных отложений. Труды ГГО. 1961. Вып. 122. С. 75-80.

10. Руднева А.В. Гололед и обледенение проводов на территории СССР. Л.: Гидрометеоиздат, 1961. $170 \mathrm{c}$.

11. Руководство по краткосрочным прогнозам погоды. Ч. І. Л.: Гидрометеоиздат. 1986. 701 с.

12. Руководство по краткосрочным прогнозам погоды. Ч. ІІ. Вып.1. Европейская часть СССР и Закавказье. Л.: Гидрометеоиздат. 1987. 298 с.

13. Настанова по службі прогнозів та попереджень про небезпечні і стихійні явища погоди. Державна гідрометеорологічна служба. Київ, 2003. 30 с.

14. Настанова гідрометеорологічним станціям і постам. Вип. 3. Ч.І. Метеорологічні спостереження на станціях. К.: Державна гідрометеорологічна служба. 2011. 279 с.

15. Роз'яснення «Настанови з метеорологічного прогнозування» від 01.01.2019 р. на заміну КД 52.4.3.01-03 (Державна гідрометеорологічна служба, Київ, 2003). Полтава. Полтавський обласний центр з гідрометеорології. Державна гідрометеорологічна служба. 2018. $35 \mathrm{c}$.

16. Настанова з метеорологічного прогнозування. Нормативний Документ. УкрГМЦ. Київ. 2019.

\section{References} $231 \mathrm{~s}$.

1. Vaynberg B.P. Sneg, iney, grad, led i ledniki . [Snow, frost, hail, ice and glaciers.]. ONTI. M.-L.:

2. Buchinskiy V.Ye. Atlas obledineniya provodov [Atlas of wire icing]. L.: Gidrometeoizdat. 1966. $116 \mathrm{~s}$.

3. Dranevich Ye.P. Gololed i izmoroz'. Usloviya obrazovaniya, prognoz i gololednoye rayonirovaniye severo-zapada Yevropeyskoy territorii SSSR [Ice and frost. Formation conditions, forecast and icy zoning of the north-west of the European territory of the USSR]. L.: Hydrometeoizdat, 1971. $228 \mathrm{~s}$. 
4. Zamorskiy A.D. Atmosfernyy led. Iney, gololed, sneg i grad [Atmospheric ice. Rime, ice, snow and hail]. M.-L.: Izd-vo Akademii nauk SSSR, 1955. 377 s.

5. Instruktsiya po podgotovke $\mathrm{k}$ rabote $\mathrm{v}$ zimniy period i organizatsii snegobor'by na zheleznykh dorogakh, v drugikh filialakh i strukturnykh podrazdeleniyakh OAO «RZHD», a takzhe yego dochernikh i zavisimykh obshchestvakh [Instructions for preparing for work in the winter and organizing snow fighting on the railways, in other branches and structural divisions of Russian Railways, as well as in its subsidiaries and dependent companies.] // Vagony i vagonnoye khozyaystvo. 2014. №3. M.: Izd-vo Rossiyskiye zheleznyye dorogi. S. 14-22.

6. Rayevskiy A.N. K voprosu o povtoryayemoti gololeda [On the issue of the repeatability of ice]. Meteorologiya i gidrologiya, 1953. №1. S. 28-31.

7. Rayevskiy A.N. Voiyaniye rel'yefa na raspredeleniye gololedno-izmorozevykh oblozheniy [The radiance of the relief on the distribution of icy-rime overlays]. Trudy OGMI. 1961. Vyp. KHKHIII. S. 3-10.

8. Rayevskiy A.N. O raspredelenii gololeda na territorii Ukrainy [About the distribution of ice on the territory of Ukraine]. Trudy UkrNIGMI. 1961. Vyp. 29. S. 50-62.

9. Rayevskiy A.N. Vliyaniye osobennostey rel'yefa na raspredeleniye gololednykh otlozheniy [The influence of relief features on the distribution of ice deposits]. Trudy GGO. 1961. Vyp. 122. S. 75-80.

10. Rudneva A.V. Gololed i obledeneniye provodov na territorii SSSR [Ice and icing of wires on the territory of the USSR]. L.: Gidrometeoizdat, 1961. $170 \mathrm{~s}$.

11. Rukovodstvo po kratkosrochnym prognozam pogody [Manual for short-term weather forecasts]. CH. Í. L.: Gidrometeoizdat. 1986. 701 s. (in Russian)

12. Rukovodstvo po kratkosrochnym prognozam pogody. Part. II. Issue 1. Yevropeyskaya chast' SSSR i Zakavkaz'ye [Manual for short-term weather forecasts. Part II. Issue 1. European part of the USSR and Transcaucasia]. L.: Gidrometeoizdat. 1987. 298 s.

13. Nastanova po sluzhbí prognozív ta poperedzhen' pro nebezpechní í stikhíyní yavishcha pogodi. Derzhavna gídrometeorologíchna sluzhba [Instruction for the service of forecasts and warnings about dangerous and natural weather phenomena. State Hydrometeorological Service]. Kiïv, 2003. $30 \mathrm{~s}$.

14. Nastanova gídrometeorologíchnim stantsíyam í postam. Vip. 3. CH.í. Meteorologíchní sposterezhennya na stantsíyakh [Instruction for hydrometeorological stations and posts. Issue 3. Part I. Meteorological observations at stations]. K.: Derzhavna gídrometeorologíchna sluzhba. 2011. $279 \mathrm{~s}$.

15. Roz'yasnennya «Nastanovi z meteorologíchnogo prognozuvannya» víd 01.01.2019 r. na zamínu KD 52.4.3.01-03 (Derzhavna gídrometeorologíchna sluzhba, Kiív, 2003). Poltava. Poltavs'kiy oblasniy tsentr z gídrometeorologiii. Derzhavna gídrometeorologíchna sluzhba. 2018. [Clarification of the "Instruction for meteorological forecasting" dated 01.01.2019 to replace CD 52.4.3.01-03 (State Hydrometeorological Service, Kyiv, 2003). Poltava. Poltava Regional Center for Hydrometeorology. State Hydrometeorological Service. 2018].

16. Nastanova z meteorologíchnogo prognozuvannya. Normativniy Dokument [Instruction from meteorological forecast. Normative Document]. UkrGMTS. Kiï. 2019. $35 \mathrm{~s}$.

Тенденции в распространении отложений изморози категории НЯ (опасная) на территории Украины в течение последнего тридцатилетия 1991-2020 гг.

Пясецкая С.И.

Статья посвящена исследованию пространственно-временного распространения отложений изморози категории НЯ (опасная) по территории Украины в течение последних 30-и лет, которые характеризуют современное состояние и динамику климатической системы в Украине и ее отдельных элементов. Целью исследования было установить особенности пространственно-временного распространения таких отложений по областям Украины по отдельным десятилетием исследуемого периода и определить тенденцию в их распространении. Доказано преобладание случаев таких отложений в январе и декабре в течение 1991-2000 г2. Однако замечено определенная тенденция в следующем десятилетии к некоторого увеличения случаев таких отложений в отдельных месяцах переходных сезонов года. Для последнего десятилетия отмечен рост таких случаев в январе и декабре по сравнению с предыдущими десятилетиями. Однако в течение последних 2-х лет количество случаев отложений изморози категории НЯ несколько уменьшилась. Доказано, что подавляющее большинство таких случаев наблюдалась на Закарпатье метеорологической станции Плай, что связано с больщей частотой появления благоприятных условий для ее образования.

Ключевые слова: отложения изморози категории НЯ (опасная), стандартный гололедных станок, распространение отложений изморози категории НЯ по территории Украины, современные изменения климата.

Trends in the spread of frost deposits of the category DP (dangerous phenomena) on the territory of Ukraine during the last thirty years 1991-2020

Pyasetska S.I.

The article is devoted to the study of spatio-temporal distribution of DP (dangerous phenomena) frost deposits on the territory of Ukraine during the last 30 years, which characterize the current state and dynamics of the climate 
system in Ukraine and its individual elements. The aim of the study was to establish the features of spatio-temporal distribution of such sediments in the regions of Ukraine for individual decades of the study period and to outline the trend in their distribution. some increase in the incidence of such deposits in some months of the transition seasons. For the last decade, there has been an increase in such cases in January and December compared to previous decades. However, during the last 2 years the number of cases of frost deposits of the DP (dangerous phenomena) category has slightly decreased. It is proved that the vast majority of such cases were observed in Transcarpathia at the meteorological station Play, which is associated with a higher frequency of favorable conditions for its formation.

Given the results of the study, we can say that in 1991-2000 the largest number of cases of frost deposits of the category of DP in Ukraine was observed in January, February and December, with January accounting for the vast majority of cases.

During January, frost deposits of the DP category were quite widely represented on the territory of Ukraine in 9 oblasts. During February and March, they were observed only in mountainous areas - in Transcarpathia and in the Autonomous Republic of Crimea. In April, October and November, such deposits were observed only in Transcarpathia at the Play meteorological station. In December, their range expanded and they were observed not only in the mountains, but also in the north, northeast and east of the country in 5 regions.

The largest number of such cases during 1991-2000 was observed in Transcarpathia (Play) and in the Autonomous Republic of Crimea (Ai-Petri).

In the period 2001-2010, the main number of cases of frost deposition of the DP (dangerous phenomena) category falls on the months of the cold period of the year, especially January and December. In contrast to the period 1991-2000, the number of cases increased in March and November, and the number of such deposits increased slightly in April.

The vast majority of cases of frost deposits of the DP (dangerous phenomena) category during 2001-2010, as well as in the previous decade, were observed in Transcarpathia at the Play weather station.

During 2011-2020, there was an increase in the number of cases of DP frost deposits in January and February compared to 2001-2010 and a slight decrease in these deposits in November and December. Also for this period, a greater localization of such sediments in Transcarpathia was established in all the studied months compared to the previous study periods, when especially in January and December such sediments were quite widespread in Ukraine.

Keywords: DP frost deposits (dangerous phenomena), standard ice machine, distribution of DP category frost deposits on the territory of Ukraine, modern climate changes.

Надійшла до редколегії 24.04.2021 